\title{
Influences of variable Anteseden functional Integrity Examiner on quality tax inspection
}

\author{
Muhammad Kasman Roem H †, Muhammad Su'un2, Hamzah Ahmad3 \\ Universitas Muslim Indonesia, Urip Sumohardjo Km. 5, Panaikang, Makassar, 90231, South Sulawesi, Indonesia
}

\begin{tabular}{|c|c|}
\hline Submission Info: & Abstract \\
\hline $\begin{array}{r}\text { Editor : Parmin Ishak } \\
\text { Received 24 Juny } 2020 \\
\text { Accepted 26 Juny } 2020 \\
\text { Available online 28 Juny } 2020\end{array}$ & $\begin{array}{l}\text { The study aims to assess the impact of competence on the integrity of tax } \\
\text { inspectors and the quality of tax inspection, competence on the quality of } \\
\text { tax inspection through the integrity of tax inspectors, independence of the } \\
\text { integrity of tax inspectors and quality of tax checks and the impact of }\end{array}$ \\
\hline $\begin{array}{r}\text { Keyword: } \\
\text { Competence } \\
\text { Independence } \\
\text { Integrity } \\
\text { Quality Inspection } \\
\end{array}$ & $\begin{array}{l}\text { descriptive analysis and path analysis with a sample number of } 80 \\
\text { respondents. This research finds that competence have a direct positive } \\
\text { and significant influence on the integrity and quality of the examination. } \\
\text { Competence positively and significantly affect the quality of tax inspection } \\
\text { through integrity. Independence has a significant positive direct influence }\end{array}$ \\
\hline $\begin{array}{r}\text { Email: } \\
\text { kasmanroem1@gmail.com } \\
\text { muhammad.suun@umi.ac.id } \\
\text { hamzah.achmad@umi.ac.id }\end{array}$ & 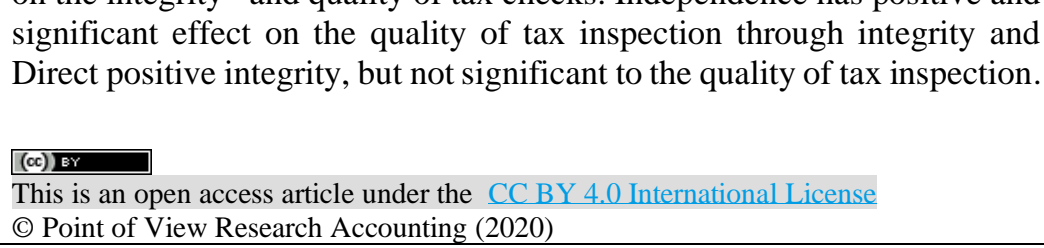 \\
\hline
\end{tabular}

\section{Introduction}

This study relates to the tax examination that has an important role in raising the taxpayer's level of compliance (Allingham \& Sandmo, 1972; Alm et al., 1992; Nuryanti, 2013). The standard of examination listed in regulation of the Director general of Taxes obliges tax inspectors to qualify for competence and integrity. The competence that the examiner should have includes knowledge in the field of Examination (Mayangsari, 2003). In addition to knowledge, examiner competence is also determined by the experience that is owned by the Examiner (Sari \& Sudana, 2013). Competence is a standard which must be met by an inspector in conducting a check to be able to perform his job with good quality results (Agoes \& Ardana, 2009; Muslim et al., 2018; Hajering et al., 2019). In addition to competence, integrity is also one that can affect the quality of inspection (Hidayat et al., 2014; Muslim, 2019). Integrity will have an impact on every decision the examiner takes in the implementation of the inspection, so it is expected that every decision taken by the examiner is the right decision (Hidayat, et al. , 2014). This indicates that if every decision taken by the examiner is always precise, the better the quality of the test is produced. Tax inspectors are required to always maintain integrity as the examiner is to have good and clean goodwill from unblemish actions and always prioritize the interests

\footnotetext{
$\dagger$ Corresponding author. Muhammad Kasman Roem H

Email address: kasmanroem1@gmail.com
} 
of the State, and be independent.

Arens, et al., (2012) states that independence in audits is an impartial perspective in the conduct of audit testing, evaluation of the results of the test, and the reporting of audit findings. Mulyadi, (2002) defines independence as a mental attitude free of influence, not controlled by other parties, and does not depend on others. Independence also means honesty in the auditor in consideration of the fact and the objective consideration is not favoring within the auditor in formulating and expressing his opinion. In the tax audit standard it is stated that the examiner must be independent, i.e. not easily influenced by the circumstances, conditions, actions and/or taxpayers that are involved. Research on the influence of independence on the quality of audits in the private sector (public accountants) has been carried out, namely the research of De Angelo, (1981) Christiawan, (2002), Mayangsari, (2003), Trisnaningsih (2007), Alim et al., (2007) who found empirical evidence that the independence affects the quality of audit. The application of Self Assesment System will be effective when the voluntary compliance condition in the community has been established. The fact in Indonesia indicates that the level of compliance is still low, this can be seen from the unoptimized tax revenues reflected by the tax gap and tax ratio (Darmayanti, 2004; Eliah, 2007; Said \& Aslindah, 2018; Sudirman \& Muslim, 2018).

In conjunction with the audit quality, Hansen \& Mowen (2009) posited, the audit quality is a degree or level of perfection for the achievement of an auditor. Audit quality is a reflection of the professional attitude of an auditor in carrying out its duties. Audit quality is very important, because with high audit quality is expected to produce relevant and reliable financial statements as the basis of decision making. The result of good audit quality in the form of transparent financial statements, can be accounted for and in accordance with the prevailing SAK, able to improve the company's performance and later the results of the financial report can be seen by stakeholders who are interested and reflect the company image in the eyes of society (uterus, $\mathrm{S}$ et al., 2019). The audit profession is considered important for the users of financial statements because the function of the audit profession is to provide adequate confidence in relation to the financial statements that have been presented by the management, through the opinions given by the auditor. The users of the audit report expect that the financial statements that have been audited by public accountants are free of material mismanagement, trustworthy and in accordance with the accounting principles applicable in Indonesia.

Until now the quality of audits is difficult to measure objectively, according to De Angelo (1981) The audit quality is a probability of an auditor to find and report on the presence of a breach in his client's accounting system. Enron's case showed that professional independence and responsibility attitudes are needed by auditors in carrying out duties and maintaining the quality of their audit work (Achmat, 2011, Grace, 2014). "The quality of auditing is determined by both competency and independency". This sentence states that the quality of the audit is determined by two things, namely competence and independence. The competent auditor is an auditor who "is able to" find violations while independent auditors are "willing" auditors to reveal the breach (Carey \& Simnett, 2006; Choi et al., 2010). The great trust of the users of the audit financial statements and services provided by public accountants requires that public accountants pay attention to the quality of the audits they produce (Nugraha, 2012; Muslim, 2019).

According to Muslim, (2019) competent auditors are auditors with sufficient knowledge and experience to conduct an objective, thorough and thorough audit. Education is an important component for an auditor in conducting audit activities. Public accountants must study, understand and apply the new provisions in the Accounting Principles and auditing standards established by the professional organization (Christiawan, 2002). Tjun et al., (2012) In his research concluded that the auditor's competence affects the quality of the resulting audits. Experienced auditors have a better understanding of the financial statements. This is demonstrated by the duration (often) Auditors audit financial statements, which means that the longer or the more often do and undergo the process of auditing increasingly capable auditors explain the sensible errors in the financial statements and can classify errors based on the purpose of auditing and the structure of the underlying accounting system.

Shafer \& Simmond, (2008) examining the relationship between competent and qualified tax inspectors can be produced and intervened from a deep taxation technical training and comprehensive. Some factors that affect the quality of tax checker results are the examiner competence. Tax inspectors are tax officers who meet the organization's requirements and criteria, which must understand carefully some of the taxation science and 
regulations and taxation law. The most important discipline is known about examination and mastery of related sciences.

Tax inspectors at KPP Madya Makassar consist of expert examiner, and skilled Examiner category. From the qualifications and competence of existing human resources all qualified accounting education which is dominated by the education of the State Accounting High School (STAN), so the tax examiner is an accountant, or a member of his. With this qualification, the Examiner competency in KPP Madya has fulfilled the competence of auditors. The phenomenon of the Tax Service office which is the sample in this study is the limited number of examiners while the inspection work to be carried out more and more complex, this is less likely to affect the quality of the work of the Examiner. In addition to the limited number of human resources, the coverage area is also very wide, so the reach of a reviewer will take a long time. In addition, there are pressures such as time, and the existence of other troubled jobs will make the target of acceptance and inspection increasingly disrupted. The tax inspectors also, must have Integritas, as well as the values of the Ministry of Finance. With the attitude of integrity, tax inspectors can face the complex of inspection tasks. The tax inspectors are always encouraged to act with the ability of high professionalism (Mulyani \& Purnomo, 2019).

Agency theory is a theory that explains the relationship between the principal and the agent (manager), where the principal delegates authority to the agent in terms of business management and decision making in the company (Jensen \& Meckling, 1976). Principal wants to know all information including management activities related to the investment or funds in the company. Principal asks a report of accountability to the agent to assess the performance of agents. However, there is often a tendency for the agent to perform an action that makes the report look good, so its performance is considered good. Attempts to reduce or minimize fraud committed by management are required testing. The test was conducted by an independent party, an independent auditor (De Angelo, 1981; Lys \& Watts et al., 1994).

The relevance of the theory with this research is very related to the science of auditing because Management will do profit management, and even do tax evasion. In the perspective of auditing sciences, both principals and agents are assumed to be people with economic rationality, where every act is motivated by personal interests or will fulfill its importance first before fulfilling the interests of others. Therefore, there is a party that takes the process of monitoring and checking the activities performed by the parties above. The activities of these Parties, assessed through its financial performance reflected in the Finance report (Muslim et al., 2018).

According to Eisenhardt, (1989) The theory of agency uses three human-disposition assumptions, namely "(1) human beings in general self-importance/self-interest, (2) Humans have limited thought about future perception/bounded rationality, and (3) humans always avoid risk averse)". Based on the third assumption of human nature, the manager (acting as agent) as human will act opportunistic, which is prioritize his personal interests. However, in this case it is not to ignore the interest of paying taxes in accordance with applicable laws and also the needs of the shareholders or the owner can be done in various ways, including with the practice of profit management in order not to violate the prevailing legislation and remain contracted again by the shareholders. In the context of the agency relationship in this research the authors connect between companies and governments who have an obligation to pay a specified amount of taxes with a number of profits accounted for. Otherwise the government has the right to accept the company's tax payments. While the right to be accepted by the company in the form of security and public service minimizes the tax obligations to be paid to the government.

The use of Teori Motivation on this research is based on the assumption that motivation is closely related to the functional performance of tax inspectors. Motives are often interpreted in the terms of encouragement. That impulse or energy is a soul and physical motion to do. So the motive is a driving force that moves people to behave, and in the reality it has a specific purpose. Every action committed by humans is always at the start with motivation (intention). According to Wexley \& Yukl, (1984), As'ad, (1987) Motivation is the gift of motif or a month, it can also be interpreted as motive or condition of motives. Meanwhile, according Winardi, (2002) The motivation represents the psychologic process, which causes the onset, its purpose, and the persistence of voluntary activities (voluntary) directed to a specific purpose. Motivation is a number of processes, which are internal, or external to an individual, which leads to an attitude of enthusiasm and persistence, in the event of carrying out certain activities (Winardi, 2012). Motivation is a complex problem in the organization, because the needs and desires of each member of the organization differ from one another. This is different because 
each member of an organization is uniquely biologically and psychologically, and develops on the basis of different learning processes (Suprihanto et al., 2003).

In 2018, Directorate General (DITJEN) withholding tax is revitalizing the tax check. This step is done to improve the fairness, quality and governance of tax check. Revitalizing the examination should be done due to tax checks is something that is often a dispute between the Directorate General of Taxes and taxpayers (WP). Many examinations are disputed until the tax Court leads. Improved inspection quality is done in order to improve the quality and accountability of inspection results, as well as maintain the integrity of the examiner, the entire inspection process will be implemented using IT-based audit under the supervision of the Inspection Quality Control Committee. Through an improvement program the examination is expected to improve the quality of the test results and suppress the potential disputes and increase the sense of fairness for WP. There are at least three main agenda in the improvement of examination procedures. The first is the efficiency of HR allocation, second, the improvement of the method of taxpayer determination examined. Third is improved inspection quality. The improvement in this examination is not just to lower the number of disputes and tax objections. However, it is also to encourage justice in tax matters. Checks must be made by a functional tax that has been pursued with adequate technical education, with the guidelines and inspection standards, and the collective work of the level. Under a system that is so orderly and clear, it is almost certainly formal inspection result will be according to standard procedures. The quality of the inspection is required to be higher than that of the implementers, so that the examiner can perform an assessment of the executive's observance of the applicable standards, and it can be achieved if the auditor has an educational background in accordance with the field examined (Setyaningrum, 2012).

More and more auditors experience can generate various assumptions in explaining the findings of the audit. (Rahim, S et al., 2020). A person who is more experiential in a substantive field has more to be stored in his memory and can develop a good understanding of the events. In order to improve the quality of the findings and ensure the final discussion of the assessment results was carried out objectively so as to produce a tax decree (SKP) that can be accounted for, then the Director general of Taxation issued a circular letter of the Director general tax number SE - 12/PJ/2016 on the affirmation of the final discussion of the examination results. This circular letter is prepared with the aim to improve the quality of the findings and ensure that the final discussion of the examination results is executed objectively resulting in a tax assessment letter that can be accounted for Inspectors as the spearhead of tax checks should be supported by the ability, willingness and balanced experience in conducting inspections. These three reflect the tax inspector's competence that should be possessed by each tax examiner, which is expected to provide work in accordance with the mission of the Directorate General of Taxation. Thus, the competence of the tax examiners becomes important in implementing the supervisory function of the Directorate General of Taxation, because in addition to the consideration in decision making results, it is also important to achieve the economical expectation of the inspection function, which is increased accuracy of tax acceptance after inspection.

The aspect of surveillance functions essentially contains a point of thought of corrective action against something that is not true by law, or it can generally be interpreted as a correction to everything that deviates from the rules. Supervisory functions include research activities, examination and investigation of criminal acts in the field of taxation. When reviewed in terms of its execution process, these activities are a process related to each other, especially in relation to the enforcement efforts of the rules taxation which aims to increase the taxpayer's compliance with its obligations on tax evasion. Tax distribution is done to inspire taxpayer compliance, in addition to giving a deterrent effect on the naughty taxpayers so as not to repeat the same deeds in the future. In addition, it is often also taxpayers to deliberately cheat on the tax payments that should be done, therefore to test its compliance should also be conducted examination.

The phenomenon of declining quality of the audit has emerged in some countries including Indonesia. A scandal that attracted public attention involving the public Accountant Office and its auditors became a warning to the audit profession to maintain its audit quality by steadfast independence in expressing fraud or mischief in financial statements. Many determinations related to the quality of the lower such as competence, independence, and integrity is considered variable will give effect on the quality of the audit. The decrease of audit Quality is caused by the competence of declining auditors. Competence Auditor is a special intelligence owned by a recognized examiner capable of using theory and practice to carry out his profession (Ulum, 2012). 
Expertise owned by an auditor must be maintained and upgraded for quality auditing results. Besides the independence competence of auditors also degraded so that impact on the quality of audit (Muslim, 2019).

This research has a difference with some previous research using variable antecedent. Pitaloka \& widanaputra, (2016) using integrity variables as competency moderate and independence the auditor found that competence and independence affect the quality of audits. Integrity auditors are able to moderate the influence of independence in audit quality, but are unable to moderate the influence of competency on audit quality. The results of this study indicate that competence and independence become variables that have a strong correlation directly. But when competence and independence are mediated by other variables of the audit quality, it hasinot been consistent. Research from kertajasa et al., (2019) using ethical variables as a moderation of competence and independence found that the competency, professional, and integrity variables positively and significantly affect the quality of the audit. The experience and independence variables do not significantly affect the audit quality. The auditors ' ethical variables do not significantly moderate competency, experience, independence, professional concern, integrity to audit quality. Subsequently Ulfah \& lukiastuti (2018) in his research the Influence of Competence and Independence toward Performance of The Government Internal Auditors with Auditor Ethics as a moderating Variable was concerned that the competency and independence of auditors had a positive and significant influence on the auditor's performance.

In his dissertation George K. Baah (2016), finding that the perception of auditors on the core determinant of audit quality is integrity and non-independence, this suggests that the auditor's profession does not focus on the fundamental character determinants of the audit quality. With these findings, the author reasons test the correlation strength of integrity as a moderation of competence and independence. There are some inconsistent research results when integrity radiated competence, so the relation of sedwill if independence has a significant relationship. This is the basis for why this research was conducted, namely to retest integrity mediation with competence and independence. Thus, the model of this research has different characteristics because the construction has two links that are direct connection and relationship indirectly because mediated by the Mediator variable, in this case is the integrity of auditors.

In direct connection here can be seen how the relationship of independent variable competency auditor affects the quality of the audit, then the second relationship directly is indirect.

\section{Research hypothesis}

H1 : Competence of positive and significant impact on tax audit integrity.

$\mathrm{H} 2$ : Competency of positive and significant effect on tax inspection quality.

H3 : Competency of positive and significant effect on tax inspection quality through integrity.

H4 : Independensi has a positive and significant impact on tax audit integrity.

H5 : Independensi has positive and significant effect on tax inspection quality.

H6 : Independensi has positive and significant effect on tax inspection quality through integrity.

$\mathrm{H} 7$ : I have an effect on the quality of tax inspection

\section{Research Method}

The research was conducted using a quantitative analytical approach. It refers to the opinion of Sugiyono, (2010) that Analytical research is a study to find facts with the right interpretation aimed at providing an overview of the phenomena, explaining the relationship, testing the hypothesis, making predictions, and obtaining the meaning and implications of a problem to be solved. This Research will be conducted at the Tax Service office of Madya Makassar, which covers the cooperation area with the offices of THE DJP region of South Sulawesi, west and southeast. The collection of research data is done by spreading the questionnaire to 80 tax inspectors. Testing the quality of the data that has been obtained will be analyzed through several stages of testing such as validity test, reliability test, mutikolinearity test, autocorrelation test, heterokedastisity test and normality test. Further to answer the research hypothesis, conducted simultaneous testing $(\mathrm{F})$, a partial test $(\mathrm{t})$ test coefficient of determination (R2). The method used in this research is path analysis. The author uses path analysis because it is to know the causal relationship, with the intention of explaining the direct or indirect influence of an exogenous variable with the endogenous variable. According to Ghozali, (2014) path analysis is part of a 
regression model that can be used to analyze causal relationships caused by a single variable with other variables. The analysis of the path is used using correlation, regression and pathways so that it can be known to arrive at the intervening variable.

\section{Result and Discussion}

\section{Result}

Theoretically a person's level of education can demonstrate a person's ability and proficiency in a particular field of work. In general it can be said the level of education of a practitioner can be worried about the intellectual ability and type of skills owned by the officer. It has become customary and common that the types and levels of education of an employee are commonly used to measure and assess the ability of an employee. Based on the data obtained, most of the respondents in this study were employees with an undergraduate education level of S-1 of 39 people or $48.75 \%$ and an educated bachelor S-2 of 20 people or $25.00 \%$ while from a Diploma in education as much as 21 people or $26.25 \%$. This illustrates that judging by the level of education tax examiner, the average employee has a level of education that belongs to the high category.

According to table 1, the validity test results show 30 question items having a high validity rate shown from the significance value $\mathrm{P}<0.05$. Thus, all items of questionnaire question are appropriate to be used for further data analysis.

Table 1. Validity Test

\begin{tabular}{|c|c|c|c|c|}
\hline Variable & Item Inquiry & $\mathrm{r}$ Hitung & Sig. & Description \\
\hline Competence & X1 1 & 0,770 & 0,000 & Valid \\
\hline \multirow[t]{3}{*}{ (X1) } & $\mathrm{X} 12$ & 0,773 & 0,000 & Valid \\
\hline & X1 3 & 0,867 & 0,000 & Valid \\
\hline & $\mathrm{X} 14$ & 0,741 & 0,000 & Valid \\
\hline Independence & $\mathrm{X} 21$ & 0,762 & 0,000 & Valid \\
\hline \multirow[t]{4}{*}{$(\mathrm{X} 2)$} & $\mathrm{X} 22$ & 0,616 & 0,000 & Valid \\
\hline & $\mathrm{X} 23$ & 0,531 & 0,000 & Valid \\
\hline & $\mathrm{X} 24$ & 0,687 & 0,000 & Valid \\
\hline & $\mathrm{X} 25$ & 0,825 & 0,000 & Valid \\
\hline Integrity & X3 1 & 0,776 & 0,000 & Valid \\
\hline \multirow[t]{4}{*}{ (Y1) } & X32 & 0,770 & 0,000 & Valid \\
\hline & X3 3 & 0,719 & 0,000 & Valid \\
\hline & X34 & 0,745 & 0,000 & Valid \\
\hline & X3 5 & 0,656 & 0,000 & Valid \\
\hline Quality inspection & X4 1 & 0,757 & 0,010 & Valid \\
\hline \multirow[t]{4}{*}{$(\mathrm{X} 4)$} & X4 2 & 0,758 & 0,000 & Valid \\
\hline & X4 3 & 0,697 & 0,000 & Valid \\
\hline & $\mathrm{X} 44$ & 0,724 & 0,000 & Valid \\
\hline & $\mathrm{X} 45$ & 0,661 & 0,000 & Valid \\
\hline
\end{tabular}

Source: Processed Data (2020)

For the next stage is the reliability test of research instruments. This test is intended to know the accuracy of the questionnaire in measuring research variables. The reliability basis if the value of the Cronbach alpha value is greater than 0.60 then the research instrument is said to be reliable. Table 2 shows that all variables have good results and meet the requirements of accuracy and reliability.

Table 2. Results of reliability test

\begin{tabular}{lccc}
\hline \multicolumn{1}{c}{ Variabel } & Alpha Cronbach & Kriteria & Description \\
\hline Competence (X1) & 0,794 & 0,60 & Reliable \\
Independence (X2) & 0,724 & 0,60 & Reliable \\
Integrity (Y1) & 0,786 & 0,60 & Reliable \\
Quality inspection (Z1) & 0,761 & 0,60 & Reliable \\
\hline
\end{tabular}

Source: Processed Data (2020) 
The Multicholininearity test aims to find out if in regression models found correlation between free variables. This test is done by calculating the value of the variance inflation factor (VIF) of each free variable. The value of the VIF < 5 indicates a good regression model and does not occur multicolinearity between free variables in a regression model. Because in this study there are two dependent variables, namely work motivation and work satisfaction while the free variables there are two namely competence and independence then multicolinearity test is done in two phases. According to table 4, The calculation results of variance inflation factor (vif) of each free variable indicating that there is no free variable that has a vif value of $>5$. Both the first stage testing for integrity dependent variables as well as the second stage testing for the dependent variable of tax quality all have values smaller than 5 . So it can be concluded that there is no multicolinearity between variables freely in the regression model.

Tabel 4. Uji Multikolinearitas

\begin{tabular}{lcc}
\hline \multicolumn{1}{c}{ Variabel } & $\begin{array}{c}\text { VIF First phase } \\
\text { (Integrity as dependent variable) }\end{array}$ & $\begin{array}{c}\text { VIF Second phase (Inspection quality as } \\
\text { dependent Varaibel) }\end{array}$ \\
\hline Competence(X1) & 1,073 & 1,073 \\
Independence(X2) & 1,073 & 1,073 \\
\hline
\end{tabular}

Source: Processed Data (2020)

Autocorrelation is a correlation between members of a sample. An autocorrelation test was performed to determine if the regression model was found to be a correlation between disruptor errors in other periods. If it happens then it is named Autocorrelation. The Result calculation of the Durbin-Watson value is 1,695 which means that there is no autocorrelation problem in this study.

Test normality is done to see if the data used is normal data. This can be noted by looking at the spread of dots on the diagonal axis of the chart. If these dots follow the diagonal line of the chart, then it can be said that the model meets the normality assumption. Figure 3 can be seen that the dots that are on the chart follow the diagonal line of the chart. This is at once indicating that the existing data is a normal distribution and fulfills the normality assumption.

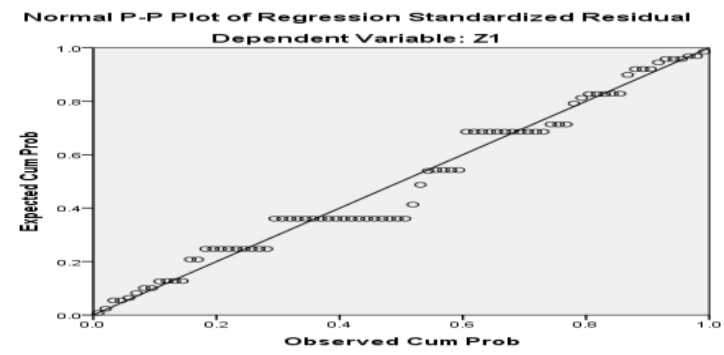

Figure 1. Normality Test

Result processing is acquired information that the entire analyzed variable has a correlation as a further analysis requirement. The resulting correlation between variables indicates that all variables have a significant correlation in alpha 0.05 with $\mathrm{P}<0.05$ which means the entire variable is significant so that advanced data analysis to test the research hypothesis by using a pathway coefficient can be performed. In order to find out the path coefficient, data analysis was conducted using analysis of the program's help Amos Ver. 22.0. In accordance with the results of data analysis of variable constellations This study obtained the following results

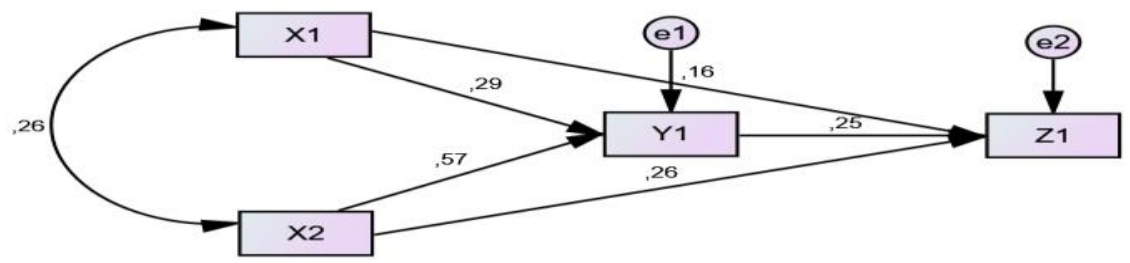

Figure 2. Model coefficient of each variable path 
Testing the significance of the pathway coefficient is done by comparing the probability value to $5 \%$ significance. The significance of the path coefficient can be seen from the AMOS output:

Table 5. Significance coefficient of Standardized line.

\begin{tabular}{cccccl}
\hline Line & Line coefficient (Beta) & Standard Error & Critical Ratio & $\mathrm{p}$ & \multicolumn{1}{c}{ Description } \\
\hline $\mathrm{pY}_{1} \mathrm{X}_{1}$ & 0,292 & 0,091 & 3,549 & 0,000 & Significant \\
$\mathrm{pY}_{1} \mathrm{X}_{2}$ & 0,572 & 0,077 & 6,948 & 0,000 & Significant \\
$\mathrm{pZ}_{1} \mathrm{X}_{1}$ & 0,159 & 0,103 & 1,507 & 0,132 & Not significant \\
$\mathrm{pZ}_{1} \mathrm{X}_{2}$ & 0,262 & 0,104 & 2,112 & 0,035 & Significant \\
$\mathrm{pZ}_{1} \mathrm{Y}_{1}$ & 0,249 & 0,119 & 1,866 & 0,062 & Not significant \\
\hline
\end{tabular}

Source: Processed Data (2020)

Based on the path test coefficient obtained an objective description that on the test, there is no statistically significant path coefficient because the value of $\mathrm{p}>0.05$ is the PZ1X1 and PZ1Y1 lines.

Table 6. Direct influence, indirect influence, and Total influence of research variables

\begin{tabular}{|c|c|c|c|c|c|}
\hline \multirow{2}{*}{ Correlation } & \multicolumn{3}{|c|}{ Effect } & \multirow[b]{2}{*}{$\mathrm{p}$} & \multirow{2}{*}{ Description } \\
\hline & Direct & Indirect & Total & & \\
\hline rX1Y1 & 0,292 & - & 0,292 & 0,000 & Significant \\
\hline $\mathrm{rX} 2 \mathrm{Y} 1$ & 0,572 & - & 0,572 & 0,000 & Significant \\
\hline rXiz1 & 0,159 & 0,073 & 0,231 & 0,132 & Not significant \\
\hline rX2Z1 & 0,262 & 0,143 & 0,404 & 0,035 & Significant \\
\hline rY1Z1 & 0,249 & - & 0,249 & 0,062 & Not significant \\
\hline
\end{tabular}

Source: Processed Data (2020)

Based on table 6, research hypothesis testing results are as follows:

Competence has a significant positive direct influence on integrity with line coefficient value 0.292 and significance rate $\mathrm{P}=0.000(\mathrm{P}<0.05)$. So the 1 st hypothesis states that competence has a positive and significant direct influence on the integrity of tax examiners proved empirically and acceptable.

Competence has a significant positive direct influence on the quality of tax inspection with a line coefficient value of 0.572 and significance level $\mathrm{P}=0.00(\mathrm{P}<0.05)$. So the 2 hypothesis that states that competence has a significant positive direct influence on the quality of the tax inspection is empirically proven.

The competency has a positive and significant effect on the quality of tax inspection through integrity with a line coefficient value of 0.159 and significance level $\mathrm{P}=0,132(\mathrm{P}>0.05)$. So the 3 hypothesis states that competence has a positive and significant influence by the quality of tax check through integrity is not empirically proven and rejected.

Independence has a significant positive direct influence on integrity with line coefficient value 0.572 and significance level $\mathrm{P}=0,000(\mathrm{P}<0.05)$. So the 4th hypothesis states that 4$)$ Independensi positively and significantly affect the integrity of tax examiners proved empiris and acceptable.

Independence has a positive and significant direct influence on the quarantine of the tax check with line coefficient value 0.262 and significance level $\mathrm{P}=0,035(\mathrm{P}<0.05)$. So the 5 hypothesis states that Independensi has positive and significant effect on tax inspection quality proved empirically and objectionable.

Independence influential positive and significant to the quality of tax inspection through integrity with the line coefficient value 0.404 and significance level $\mathrm{P}=0,035(\mathrm{P}<0.05)$. So the 6 hypothesis that states that Independensi positively and significantly affect the quality of tax inspection through integrity is empirically proven and acceptable.

Direct impact integrity is positive but not significant to the quality of tax inspection with a line coefficient value of 0.249 and significance level $\mathrm{P}=0,062(\mathrm{P}>0.05)$. So the 7 th hypothesis states that integrity has a positive and significant direct influence on the quality of tax checks is not empirically proven and rejected. 


\section{Discussion}

Based on the results of the study found that competence has a significant direct positive influence on integrity. The results of this research in line with the philosophy in the Ministry of Finance work environment that integrity is also one of the values of the Ministry of Finance should ideally materialize in every employee of the Ministry of Finance. Integrity according to the values of the Ministry of Finance is defined as thinking, saying, behave properly and properly and uphold the code of ethics and moral principles.

Integrity is acting consistently in accordance with organizational values and policies as well as the professional code of ethics, even in circumstances where it is difficult to do so. Simply put, integrity demonstrates the firmness of attitude, stating the deeds and moral values embraced by a person. People who have integrity will not be shaken by the temptation to betray the moral values that are believed. Personal integrity is a person who maintains a high level of honesty and ethics in his daily words and actions. The results of this study are in line with George K. Baah's research (2016), which found that competence affects ethical behavior.

Based on the results of research analysis found that the competencies influence significant positive to the quality of tax inspectors. Based on the variable data of competency variables have an indicator knowledge, experience, maturity, and well-trained. The result of an count on the Frequency table shows that competence has a very high value of responsiveness. The results of this research are in line with the opinions of experts such as Arens et al., (2011) stating that competence is knowledge and skills needed in the work. This also means that a tax assessment should have the competence and skills in the form of knowledge both generally and specifically such as professional knowledge, having experience of examination, having maturity, and trained in every condition and field of examination. The result of this research is in line with a motivation theory related to three conditions that encourage behavior, behavior that is encouraged by the circumstances, and the purpose of the behavior. Related to the competency of tax inspectors, haula Rosdiana \& Edi Slamet (2011) explained that the tax audit competence consists of hard competency and soft competency. In the hard competency, tax inspectors meet the requirements of adequate technical competence in the areas of taxation, accounting and inspection, have general knowledge of the environment and the taxpayer business processes, and the ability to apply accounting principles that apply. While soft competency tax inspectors consist of clearly and effectively communicating skills, both orally and in writing and capable of professional skills, accuracy and, objective, independent, and always maintain integrity. The results are in line with the research of Kertajasa et al ., (2019) which found that the competencies have a positive and significant effect on the quality of inspection. The study also supported the findings of Pitaloka \& widanaputra, (2016) who found that the competencies were positively and significantly influential for quality inspectors. The same research with this research is Halim et al., (2014), and damayanti et al., (2015) who found that both competence and work experience have an effect on audit quality. It also justifying that in the indicator of work experience there is the nature of maturity, and the training of the tax inspectors. So that the substantive indicators used in this study are reliable (ulfah \& lukiastuti , (2018) also found the same findings as the current researchers.

Based on the results of the study found that integrity was not able to process competence with audit quality. This means that the competency only directly affects the quality of the examination. The results of this study are in line with the studies already mentioned in the second hypothesis. The absence of a mediation link in this hypothesis can be explained that the tax examiner who has the competence does not necessarily have integrity, this is because if it is associated with an indicator of integrity, it can automatically be emphasized that the indicator of honesty, sincerity, trust, and refrain from misdeeds is an indicator of the nature of the abstract space. Integrity is the unwavering consistency and firmness in upholding sublime values and beliefs (the integrity Guide can also be interpreted as the honesty and truthfulness of a person's actions in daily life. From this sense of integrity shows that integrity is in each tax examiner. This can be strengthened by the cultural values of the Ministry of Finance or Cultural Organization. The concept of integrity in itself identifies with the word heart, moral accountability, moral commitment, and moral consistency between the conduct and certain values or principles (Paine, 1994). Competence as the personal aspects of a worker allows him to achieve superior 
performance. These personal aspects include traits, motives, values, attitudes, knowledge and skills where competence will lead behavior, while conduct will result in performance.

Based on the results the study found that independence was positive and significant to the examiner integrity. It is that the fourth hypothesis in this study was received. The results of this study show that independence is human nature, not the nature of the examiner, or the tax examiner. Auditor's only formal duties. Therefore, as human and auditor, it automatically has an ambivalence from the side of the answer. It is human responsibility and as an auditor. In this case Gunz, (1991), Mautz \& Sharaf (1993), (Reiter \& Williams, (2005), suggests that independence is a central issue of ethics in accountability. Results in the direction of the research in Riswan (2012) which says that the independent attitude of the examiner is often contrary to external interests (Bazerman, 1997). Therefore, moral and ethical aspects are a key element that a reviewer must have and possess high integrity and objectivity. Moral and ethical awareness is interpreted as an individual's ability to evaluate and consider ethical values in an event. The results of this study according to the authors if these two variables are independence and integrity can not influence each other, because both have a common trait, but so can also be said that the examiner is independent because he has integrity. This means that both variables are complementary variables with quality checks

Based on the results of the study found that independence was positive and significant to the quality of tax inspection. The findings support the research of Halim, et al., (2014). The I Found the significant independencies positif and significantly against the quality of auditors. The results of this study were also in line with Ulfah \& lukiastuti (2018). Which found that independence affects the quality of internal auditors. Kertajasa et al., (2019) In his research was different from this research because his findings stated that independence is not as important as the examination of the quarantine. It is also said that a tax inspector is Independen, meaning he must have a mental attitude that is free of influence, not controlled by others, not dependent on others. Independence can also be interpreted as honesty in considering facts.

Based on the results of the study it was found that Independence has a positive and significant effect on tax inspection quality through integrity. Based on the answer taken is known that total value scores and index variable independence belong to the very high category. This means that integrity is capable of the dissemination of the relationship between independence and the quality of tax audit. The results of this research in line with the research of Halim, et al., (2014). In another study, Nizarul et al., (2007), Yossi septriani (2012) proved that independence has a significant effect on the quality of the audit, while Tjun et al., (2012) stated that independence had no significant effect on the quality of the audit.

Based on the results of the study found that integrity directly affects positive but not significant to the quality of tax inspection. The results of this research supported the research of Kertajasa et al., (2019) stating that the integrity has a significant positive effect on the quality of inspection. The results of this study in line with research. Damayanti 's et al., (2015) stating this insignificant need to explain that the difference between statistical significance (statistical significance) and practical significance (practical significance). Significance does not always have the concomitant meaning. Statistical significance can indeed be calculated and therefore can be demonstrated objectively, but from the practical side, the presence of practical significance needs to be based on resourceful consideration (Diekhoff, 1992). This is due to the significant fact that a statistic is tested depends on the size of the sample (n) and the data variability. Statistical significance is a statement about the possible results observed, nothing else. It does not guarantee that something important, or even meaningful, has been found ". Not a significant integrity with the quality of this inspection means that the relationship is not very real with the quality of the examination. The results of this research do not support the research of the Services of Kertajasa et al., (2019) which found that the integrity effect positive and significant to the quality of the audit.

\section{Conclusions}

The results of this study confirm's that integrity is essential to an organization, because it always relates to the philosophy, ideology, values, assumptions, beliefs, hopes, attitudes and norms that are shared and binding 
within a particular organization. Competence has a very important meaning in improving the quality of the examination. Increasing the level of competency of tax inspectors will improve inspection quality. The results of this study suggested that tax Examiner's turnover should be further improved to ensure the quality of tax checks. The independence of the tax examiner should be maintained by implementing the values of organization that can strengthen the examiner, and the integrity examiners remain preserved so that the quality of tax audit remains the hope of the future organization.

\section{References}

Achmat, B. (2011). Faktor-faktor yang Berpengaruh Terhadap Kualitas Audit Auditor Independen Pada Kantor Akuntan Publik Di Jawa Tengah. Dinamika Keuangan dan Perbankan, 183-197.

Agoes, S., \& Ardana, I. C. (2009). Etika bisnis dan profesi: tantangan membangun manusia seutuhnya. Penerbit Salemba.

Alim, M. N. dkk., 2007. Pengaruh Kompetensi dan Independensi Terhadap Kualitas Audit dengan Etika Auditor Sebagai Variabel Moderasi, Simposium Nasional Akuntansi X Makasar, 26-28.

Allingham, M. G., \& Sandmo, A. (1972). Income tax evasion: A theoretical analysis. Journal of public economics, 1(3-4), 323-338.

Alm, J., Jackson, B. R., \& McKee, M. (1993). Fiscal exchange, collective decision institutions, and tax compliance. Journal of Economic Behavior \& Organization, 22(3), 285-303.

Anugrah, R. J. (2014). Pengaruh Profesionalisme, Independensi, Dan Kompetensi Auditor Terhadap Kualitas Audit Pada Kap Di Surabaya (Doctoral dissertation, STIE Perbanas Surabaya).

Arens, A. A., Elder, J. R., \& Beasley, S. M. Amir Abadi Jusuf. (2011). Auditing and Assurance Service an Integrated Approach-An Indonesian Adaptation.

Arens, A.A., R.J. Elder, dan M.S. Beasley. (2012). Auditing and Assurance Services: An Integrated Approach.Fourteenth Edition. New Jersey: Prentice Hall International Inc.

As'ad, Muhammad. (1987). Psikologi Industri, Edisi Ketiga. Yogyakarta: Penerbit. Lyberti.

Baah, G. K. (2016). The Intersection of Auditor Independence, Objectivity, and Integrity in High-risk Audit Conditions (Doctoral dissertation, Case Western Reserve University).

Bazerman, M. H., Morgan, K. P., \& Loewenstein, G. F. (1997). The impossibility of auditor independence. Sloan Management Review, 38, 89-94.

Carey, P., \& Simnett, R. (2006). Audit partner tenure and audit quality. The accounting review, 81(3), 653-676.

Choi, J. H., Kim, C., Kim, J. B., \& Zang, Y. (2010). Audit office size, audit quality, and audit pricing. Auditing: A Journal of practice \& theory, 29(1), 73-97.

Christiawan, Y. J. (2002). Kompetensi dan independensi akuntan publik: refleksi hasil penelitian empiris. Jurnal Akuntansi dan Keuangan, 4(2), 79-92.

Damayanti, T. W., Subekti, I., \& Baridwan, Z. (2015). Trust and uncertainty orientation: An efforts to create tax compliance in social psychology framework. Procedia-Social and Behavioral Sciences, 211, 938-944.

Darmayanti, T. W. (2004). Pelaksanaan Self Assesment System Menurut Wajib Pajak (Studi Kasus pada Wajib Pajak Badan Salatiga). Jurnal Ekonomi dan Bisnis, 10(1), 109-128.

DeAngelo, L. E. (1981). Auditor size and audit quality. Journal of accounting and economics, 3(3), 183-199.

Diekhoff, G. (1992). Statistics for the social and behavioral sciences. Dubuque, IA: Wm. C. Brown.

Elia, M. (2007). Kepatuhan Wajib Pajak Badan (Kajian Empiris di Perusahaan Industri Pengolahan di Surabaya). Simposium Nasional Akuntansi X. Unhas Makassar.

Eisenhardt, K. M. (1989). Agency theory: An assessment and review. Academy of management review, 14(1), 5774.

Ghozali, I. (2014). Model Persamaan Struktural: Konsep dan Aplikasi dengan Program AMOS 22.0 Update Bayesian SEM. Semarang: Badan Penerbit Universitas Diponegoro.

Gunz, S., \& McCutcheon, J. (1991). Some unresolved ethical issues in auditing. Journal of Business Ethics, 10(10), 777-785.

Halim, A., Sutrisno, T., \& Achsin, M. (2014). Effect of Competence and Auditor Independence on Audit Quality with Audit Time Budget and Professional Commitment as a Moderation Variable. International Journal of Business and Management Invention, 3(6), 64-74.

Hansen, D., \& Mowen, M. (2009). Managerial Accounting eight edition. South Western: Thomson. 
Haula, R., Putranti, T. M., \& Irianto, E. S. (2011). Teori Pajak Pertambahan Nilai: Kebijakan dan Implementasinya di Indonesia. Jakarta: Ghalia Indonesia.

Hidayat, R., Andreas, A., \& Ilham, E. (2014). Pengaruh pengalaman kerja, etika, integritas, dan motivasi terhadap kualitas audit (Studi empiris pada auditor BPKP Provinsi Riau) (Doctoral dissertation, Riau University).

Ihyaul Ulum, M. D. (2012). Audit Sektor Publik. Jakarta, Bumi Aksara.

Jensen, M. (1976). Meckling. 1976. Theory of the Firm: Managerial Behaviour, Agency Costs, and Ownership Structure, 22.

Kertarajasa, A. Y., Marwa, T., \& Wahyudi, T. (2019). The effect of competence, experience, independence, due professional care, and auditor integrity on audit quality with auditor ethics as moderating variable.

Lys, T., \& Watts, R. L. (1994). Lawsuits against auditors. Journal of accounting research, 32, 65-93.

Mautz, R. K., \& Sharaf, H. A. (1993). The Philosophy of Auditing, Sarasota, Florida: American Accounting.

Mayangsari, S. (2003). Pengaruh Keahlian Audit dan Independensi terhadap Pendapat Audit: Sebuah Kuasieksperimen. The Indonesian Journal of Accounting Research, 6(1).

Mulyadi. (2002). Auditing. Jakarta: Salemba Empat.

Mulyani, S. D., \& Purnomo, T. H. (2019). Peran Kompleksitas Tugas Dalam Hubungan Kompetensi, Independensi, Dan Etika Pemeriksa Pajak Dengan Kualitas Hasil Pemeriksaan. Esensi: Jurnal Bisnis dan Manajemen, 9(1), 109-118.

Muslim, M., Pelu, M. F. A., \& Mentari, K. S. (2018). Pengaruh Kompetensi Auditor, Tekanan Ketaatan, dan Kompleksitas Tugas Terhadap Audit Judgment. Bongaya Journal for Research in Accounting (BJRA), 1(2), 08-17.

Muslim, M. (2019). Pengaruh Kompetensi, Independensi, Integritas Dan Motivasi Kerja Auditor Terhadap Kualitas Audit APIP Pada Inspektorat Provinsi Sulawesi Selatan.

Nizarul, T. Liliek. 2007. Pengaruh Kompetensi dan Independensi terhadap Kualitas Audit dengan Etika sebagai Variabel Moderasi. SNA X. Makassar.

Nugraha, M. E. (2012). Pengaruh Independensi, Kompetensi dan Profesionalisme terhadap kualitas audit (Doctoral dissertation, Widya Mandala Catholic University Surabaya).

Nuryanti, Dwi. 2013. Pengaruh Tingkat Kepatuhan Wajib Pajak Badan terhadap Peningkatan Penerimaan Pajak yang di Moderasi oleh Pemeriksaan Pajak pada KPP Pratama (Studi Kasus di Surakarta). Skripsi, Universitas Muhammadiyah Surakarta. Tidak Dipublikasikan.

Paine, L. S. (1994). Managing for organizational integrity. Harvard business review, 72(2), 106-117.

Pitaloka, Y., \& Widanaputra, A. A. G. P. (2016). Integritas Auditor Sebagai Pemoderasi Pengaruh Kompetensi Dan Independensi Pada Kualitas Audit. E-Jurnal Akuntansi Universitas Udayana, 16(2), 1574-1603.

Rahim, S., Muslim, M., \& Amin, A. (2019). Red Flag And Auditor Experience Toward Criminal Detection Trough Profesional Skepticism. Jurnal Akuntansi, 23(1), 47-62.

Rahim, S., Ahmad, H., Nurwakia, N., Nurfadila, N., \& Muslim, M. (2020). The Influence of Audit Staff Quality and Client Type on Audit Evidence Collection with Communication Type as Moderation. Journal of Accounting and Strategic Finance, 3(1), 103-117.

Reiter, S. A., \& Williams, P. F. (2005). The history and rhetoric of auditor independence concepts.

Riswan, R. (2012). Pengaruh Independensi Dan Komitmen Organisasi Terhadap Kualitas Audit (Studi pada Kantor Akuntan Publik di Bandar Lampung, Bandung, dan Jakarta). Jurnal Manajemen dan Bisnis, 2(2).

Said, S., \& Aslindah, A. (2018). Pengaruh Penerapan E-System Perpajakan Terhadap Kepatuhan Wajib Pajak Orang Pribadi (Studi Pada KPP Pratama Makassar Selatan). ATESTASI: Jurnal Ilmiah Akuntansi, 1(1), 29-39.

Sari, N. P. I. P., \& Sudana, I. P. (2013). Pengaruh Kompetensi dan Independensi Auditor pada Kualitas Proses Audit. E-Jurnal Akuntansi Universitas Udayana, 3(1), 136-158.

Septriani, Y. (2012). Pengaruh Independensi Dan Kompetensi Auditor Terhadap Kualitas Audit, Studi Kasus Auditor Kap Di Sumatera Barat. Jurnal Akuntansi \& Manajemen, 7(2), 78-100.

Setyaningrum, D. (2012). Analisis faktor-faktor yang mempengaruhi kualitas audit BPK RI. Paper dipresentasikan pada Simposium Nasional Akuntansi XV, Banjarmasin.

Shafer, W. E., \& Simmons, R. S. (2008). Social responsibility, Machiavellianism and tax avoidance. Accounting, Auditing \& Accountability Journal.

Sudirman, S., \& Muslim, M. (2018). Analisis Faktor-Faktor Yang Mempengaruhi Manajemen Perusahaan Melakukan Tax Planning (Studi Empiris Pada Wajib Pajak Yang Terdaftar Di KPP Madya Makassar). CESJ:

Center Of Economic Students Journal, 1(1), 1-13.

Suprihanto, John. (2003). Riset Sumber Daya Manusia Dalam Organisasi. Jakarta: PT. Gramedia Pustaka Utama. 
Sugiono. (2010). Metode Penelitian Kuantitatif, Kualitatif, dan R\&D. Bandung: Alfabeta.

Hajering, M. S. (2019). Moderating Ethics Auditors Influence of Competence, Accountability on Audit Quality. Jurnal Akuntansi, 23(3), 468-481.

Tjun, L. T., Marpaung, E. I., \& Setiawan, S. (2012). Pengaruh kompetensi dan independensi auditor terhadap kualitas audit. Jurnal akuntansi, 4(1), 33-56.

Trisnaningsih, S. (2007). Independensi auditor dan komitmen organisasi sebagai mediasi pengaruh pemahaman good governance, gaya kepemimpinan dan budaya organisasi terhadap kinerja auditor. Simposium Nasional Akuntansi X, 10, 1-56.

Ulfah, U. M., \& Lukiastuti, F. (2018). Pengaruh Kompetensi Dan Independensi Pada Kinerja Auditor Internal Pemerintah Dengan Etika Auditor Sebagai Variabel Moderasi (Studi Pada Inspektorat Kabupaten Tegal). Jurnal Manajemen Teori dan Terapan| Journal of Theory and Applied Management, 11(1), 39-50.

Wexley, K. N., \& Yukl, G. A. (1984). Organizational behavior and personnel psychology. Richard D. Irwin.

Winardi, J. (2002). Motivasi dan pemotivasian dalam manajemen. Jakarta: PT. Raja Grafindo Persada. 